Annals of Plant and Soil Research 23(2): 200-203 (2021)

https://doi.org/10.47815/apsr.2021.10057

\title{
Genetic variability, heritability and genetic advance in bottle gourd [Lagenaria siceraria (molina) standl.] genotypes
}

\author{
M. VENKATRAMAN ${ }^{\star 1}$ AND K. HARIPRIYA ${ }^{2}$ \\ Department of Horticulture, Faculty of Agriculture, Annamalai University, Annamalai Nagar - 608 002, \\ Tamilnadu, India
}

Received: February, 2021; Revised accepted: March, 2021

\begin{abstract}
An experiment was carried out to analyze genetic variability for yield and its contributing characters in 35 bottle gourd genotypes in randomized block design with three replications to assess the nature and magnitude of association among yield and its contributing traits in bottle gourd (Lagenaria siceraria). Results indicated that PCV and GCV were high (more than 20\%), sex ratio for PCV was $34.19 \%$ and GCV registered as 24.79 per cent, respectively. Moderate PCV $(14.28,16.10)$ and GCV $(13.78,13.43)$ were recorded for vine length and primary branches, respectively. The high genetic advance as per cent of mean along with high heritability was obtained for vine length $(0.93 \%)$, fruit length $(0.87 \%)$, fruit width $(0.76 \%)$, primary branches $(0.69 \%)$, fruits per vine $(0.59 \%)$, sex ratio $(0.52 \%)$, fruit yield $(0.44 \%)$, days to first female flower anthesis $(0.42 \%)$, node at first female flower appears $(0.41 \%)$, days to first harvest $(0.40 \%)$, fruit thickness $(0.37 \%)$, days to first male flower anthesis (0.37\%), fruit weight (0.35\%) and node at first male flower appears $(0.20 \%)$.
\end{abstract}

Key words : Bottle gourd, variability, GCV, PCV, heritability, genetic advance.

\section{INTRODUCTION}

Bottle gourd (Lagenaria siceraria (Mol) Standl) is one of the most important vegetable crop in India. It is a highly cross pollinated crop due to its monoecious and andromonoecious nature. It belongs to the family cucurbitaceae having chromosome number $2 \mathrm{n}=22$. It has a good amount of vitamins and minerals. Fruits are rich in 95.54\% moisture, vitamin C (10.1 g), vitamin $A(16 \mathrm{IU})$, thiamine $(0.029 \mathrm{~g})$, riboflavin $(0.022 \mathrm{~g})$, niacin $(0.320 \mathrm{~g})$, carbohydrates $(3.39$ $\mathrm{g})$, fats $(0.02 \mathrm{~g})$ and potassium $(150 \mathrm{mg}) / 100 \mathrm{~g}$. Being cross-pollinated crop; it exhibits wide range of variability for maturity, yield and fruit characters like shape and size. The fruit color varies from dark green to cream or yellow. Significant regional variability has been reported in India by Sivaraj and Pandravada (2005). The available diversity within the species for desired fruit enables a breeder in choosing elite genotypes. Parameters of genotypic and phenotypic coefficient of variation (GCV and PCV) are useful in detecting the amount of variability present in the available genotypes. Heritability and genetic advance help in determining the influence of environment in expression of the characters and the extent to which improvement is possible after selection. The present investigation was, therefore, taken under to ascertain magnitude and extent of genetic variability, heritability and genetic advance in thirty five varieties of bottle gourd. These genotypes represent released varieties (10), land races (7), accessions (7) and regional specific open pollinated varieties (11). The present study was conducted to analyze genetic variability for yield in bottle gourd.

\section{MATERIALS AND METHODS}

The study was carried out at vegetable unit, Department of Horticulture, Faculty of Agriculture, Annamalai University, Chidambaram during Jan-Mar 2020. Experimental site is situated at 11.24 ' $\mathrm{N}$ latitude and $79.41^{\prime} \mathrm{E}$ longitude at an altitude of $4 \mathrm{~m}$ above mean sea level. The material for the present study consisted of thirty five diverse genotypes. The experiment was laid out in the randomized block design with three replications. Each treatment or a genotype in each replication was represented by two rows each accommodating 10 plants in a row. Row to row spacing was $1.8 \mathrm{~m}$ and $0.9 \mathrm{~m}$ 
was maintained between plants from within a row. Five plants were randomly selected in each genotype from each replication and labeled for recording observation on quantitative characters. All recommended cultural and management practices were followed to maintain the crop healthy. The mean values of the data recorded were analyzed statistically adopting the method suggested by Panse and Sukhatme (1985). The magnitude of phenotypic co-efficient of variation (PCV) and genotypic co-efficient of variation (GCV) existing in a trait was worked out by the formula given by Burton (1952). PCV and GCV were categorized as low, moderate and high by following Johnson et al. (1955) as (0 10\%): Low, (10 -20\%): Moderate, (Above 20\%): High respectively. Heritability in broad sense was estimated as per the procedure presented by Burton and Devane (1953). The heritability percentage was categorized as low, moderate and high as suggested by Robinson et al. (1949) (0-30\%): Low, (3060\%): Moderate and (60\% and above): High respectively. Genetic advance at 5 per cent selection intensity was worked out by using the formula given by Johnson et al. (1955). The Genetic advance as per cent of mean was categorised as low, moderate and high by following Johnson et al. (1955) Low 0-10\%, Moderate $10-20 \%$ and High $20 \%$ and above.

\section{RESULTS AND DISCUSSION}

The ANOVA revealed significant differences indicating that there are enough variation among all the germplasm, for all fifteen characters studied viz, vine length, primary branches, node at first male flower appears, node at first female flower appears, days to first male flower anthesis, day to first female flower anthesis, sex ratio, days to first harvest, fruit length, fruit width, fruit flesh thickness, fruit weight, fruits per vine and yield per vine. The range in the values reflect the amount of phenotypic variability. As this is not very reliable since it includes genotypic, environmental and genotype $x$ environmental interaction components and does not reveal as to which characters is showing higher degree of variability. Further, the phenotype of crop is influenced by additive gene effect (heritable), dominance (non-heritable) and epistasis (no allelic interaction). Hence, it becomes necessary to split the observed variability into phenotypic coefficient of variation and genotypic coefficient of variation, which ultimately indicates the extent of variability existing for various traits.

Table 1: Analysis of variance with respect to MSS for various characters in bottle gourd

\begin{tabular}{|c|c|c|c|c|c|c|c|c|c|}
\hline \multirow[b]{2}{*}{$\begin{array}{l}\text { Source of } \\
\text { variation }\end{array}$} & \multirow[b]{2}{*}{ d.f } & \multicolumn{8}{|c|}{ Mean sum of squares } \\
\hline & & $\begin{array}{l}\text { Vine } \\
\text { length }\end{array}$ & $\begin{array}{c}\text { Primary } \\
\text { branches }\end{array}$ & \begin{tabular}{|c|}
$\begin{array}{c}\text { Node at first } \\
\text { male flower } \\
\text { appears }\end{array}$ \\
\end{tabular} & $\begin{array}{c}\text { Node at first } \\
\text { male flower } \\
\text { appears }\end{array}$ & $\begin{array}{c}\text { Node at first } \\
\text { male flower } \\
\text { appears }\end{array}$ & \begin{tabular}{|c|} 
Node at first \\
male flower \\
appears
\end{tabular} & $\begin{array}{l}\text { Sex } \\
\text { ratio }\end{array}$ & $\begin{array}{l}\text { Days to } \\
\text { first } \\
\text { harvest }\end{array}$ \\
\hline Replication & 2 & 670.97 & 0.91 & 0.40 & 0.13 & 0.86 & 2.22 & 0.26 & 4.01 \\
\hline Genotypes & 34 & 5421.82 & 4.01 & 1.08 & 1.96 & 6.94 & 2.01 & 0.05 & 3.21 \\
\hline Error & 68 & 129.85 & 0.51 & 0.60 & 0.63 & 2.44 & 0.63 & 0.01 & 1.05 \\
\hline \multirow{2}{*}{$\begin{array}{l}\text { Source of } \\
\text { variation }\end{array}$} & & \multicolumn{8}{|c|}{ Mean sum of squares } \\
\hline & d.f & $\begin{array}{l}\text { Fruit } \\
\text { length }\end{array}$ & $\begin{array}{l}\text { Fruit } \\
\text { width }\end{array}$ & Fruit cavity & $\begin{array}{l}\text { Fruit flesh } \\
\text { thickness }\end{array}$ & Fruit weight & $\begin{array}{l}\text { Fruits per } \\
\text { vine }\end{array}$ & \multicolumn{2}{|c|}{ Yield per vine } \\
\hline Replication & 2 & 2.06 & 0.23 & 0.28 & 0.00 & 0.11 & 0.12 & \multirow{3}{*}{\multicolumn{2}{|c|}{$\begin{array}{c}5.39 \\
19.55 \\
5.69\end{array}$}} \\
\hline Genotypes & 34 & 16.41 & 7.64 & 1.59 & 0.15 & 0.26 & 0.57 & & \\
\hline Error & 68 & 0.77 & 0.71 & 0.06 & 0.05 & 0.10 & 0.10 & & \\
\hline
\end{tabular}

Results from the present study indicated that PCV and GCV were high (more than $20 \%$ ), sex ratio for PVC was 34.19 per cent and GCV was registered as 24.79 per cent, respectively. Moderate PCV $(14.28,16.10)$ and GCV $(13.78,13.43)$ were recorded for vine length and primary branches, respectively. High estimates of genotypic and phenotypic coefficient of variation for fruit length were also observed by
Singh et al., (2014). The difference among the genotypic coefficient of variance and phenotypic coefficient of variance value for different characters indicated that the influence of environment in expressing the variability with there traits. Hence the breeders are to select superior genotypes on the basis of phenotypic expression of quantitative traits as stated by Johnson at el., (1955). 
The high genetic advance as per cent of mean along with high heritability was obtained for vine length $(0.93 \%)$, fruit cavity $(0.88 \%)$, fruit length $(0.87 \%)$, fruit width $(0.76 \%)$, primary branches $(0.69 \%)$, fruit per vine $(0.59 \%)$, sex ratio $(0.52 \%)$, fruit yield $(0.44 \%)$, days to first female flower anthesis $(0.42 \%)$, node at first female flower appears $(0.41 \%)$, days to first harvest $(0.40 \%)$, fruit thickness $(0.37 \%)$, days to first male flower anthesis $(0.37 \%)$, fruit weight $(0.35 \%)$ and node at first male flower appears $(0.20 \%)$.

Table 2: Estimates of Genetic Variability parameters for various quantitative characters in bottle gourd

\begin{tabular}{|c|c|c|c|c|c|c|c|c|}
\hline SI.No & Mean & Range & $\begin{array}{c}\text { Phenotypic } \\
\text { variance } \\
(\mathrm{PV})\end{array}$ & $\begin{array}{c}\text { Genotypic } \\
\text { variance } \\
\text { (GV) }\end{array}$ & $\begin{array}{c}\text { Genotypic } \\
\text { coefficient } \\
\text { of variation } \\
\text { (GCV) }\end{array}$ & $\begin{array}{c}\text { Phenotypic } \\
\text { coefficient } \\
\text { of variation } \\
\text { (PCV) }\end{array}$ & $\begin{array}{c}\text { Heritability } \\
\mathrm{h}^{2} \\
\text { (broad } \\
\text { sense) }\end{array}$ & $\begin{array}{c}\text { Genetic } \\
\text { advance } \\
\text { (as } \\
\% \text { of } \\
\text { mean) }\end{array}$ \\
\hline Vine length & 304.69 & $202.33-401.12$ & 1893.84 & 1763.99 & 13.78 & 14.28 & 0.93 & 27.40 \\
\hline Primary branches & 8.04 & $5.86-11.17$ & 1.67 & 1.16 & 13.43 & 16.10 & 0.69 & 23.07 \\
\hline $\begin{array}{l}\text { Node at first male } \\
\text { flower appears }\end{array}$ & 8.46 & $7.23-9.30$ & 0.76 & 0.16 & 4.73 & 10.33 & 0.20 & 4.46 \\
\hline $\begin{array}{l}\text { Node at first } \\
\text { female flower } \\
\text { appears }\end{array}$ & 13.20 & $11.48-14.98$ & 1.08 & 0.44 & 5.04 & 7.87 & 0.41 & 6.65 \\
\hline $\begin{array}{l}\text { Days to first male } \\
\text { flower anthesis }\end{array}$ & 42.95 & $40.56-46.47$ & 3.94 & 1.49 & 2.84 & 4.62 & 0.37 & 3.61 \\
\hline $\begin{array}{l}\text { Days to first } \\
\text { female flower } \\
\text { anthesis }\end{array}$ & 48.90 & $47.58-51.29$ & 1.09 & 0.46 & 1.38 & 2.13 & 0.42 & 1.85 \\
\hline Sex ratio & 0.48 & $0.19-0.72$ & 0.02 & 0.01 & 24.79 & 34.19 & 0.52 & 37.03 \\
\hline $\begin{array}{l}\text { Days to first } \\
\text { harvest }\end{array}$ & 60.80 & $58.12-62.91$ & 1.77 & 0.71 & 1.39 & 2.19 & 0.40 & 1.82 \\
\hline Fruit length & 38.25 & $33.46-43.03$ & 5.98 & 5.21 & 5.96 & 6.39 & 0.87 & 11.46 \\
\hline Fruit width & 23.30 & $20.16-26.89$ & 3.02 & 2.30 & 6.52 & 7.46 & 0.76 & 11.73 \\
\hline Fruit cavity & 7.75 & $6.23-9.35$ & 0.57 & 0.50 & 9.19 & 9.78 & 0.88 & 17.79 \\
\hline $\begin{array}{l}\text { Fruit flesh } \\
\text { thickness }\end{array}$ & 1.62 & $1.23-2.33$ & 0.08 & 0.03 & 11.07 & 18.09 & 0.37 & 13.97 \\
\hline Fruit weight & 1.78 & $1.40-2.38$ & 0.15 & 0.05 & 13.21 & 22.19 & 0.35 & 16.21 \\
\hline $\begin{array}{l}\text { Number fruits per } \\
\text { vine }\end{array}$ & 2.53 & $1.96-3.58$ & 0.26 & 0.15 & 15.51 & 20.20 & 0.59 & 24.55 \\
\hline Yield per vine & 16.99 & $11.98-22.35$ & 10.31 & 4.62 & 12.64 & 18.89 & 0.44 & 17.44 \\
\hline
\end{tabular}

The presence of heritability and additive gene action in the present study were supported by the findings of Sanwal et al., (2007) in sweet gourd, Kumar et al., (2008), Hanchinamani et al., (2011) and Kumar et al., (2013) in cucumber, Samadia (2011), Jat et al., (2014) in kakri, and by Singh et al., (2014) in bitter gourd. From the present study, it is obvious that genotypes studied may provide good source of material for advance breeding programme. Therefore, information on the genetic parameters such as genetic correlation coefficient, coefficient of variation, heritability and genetic advance can help the breeder to develop suitable cultivars within a short time.

On the basis of results as summarized above, it is concluded that traits like vine length, primary branches, node at first male flower appears, node at first female flower appears, days to first male flower anthesis, day to first female flower anthesis, sex ratio, days to first harvest, fruit length, fruit width, fruit flesh thickness, fruit weight, number of fruits per vine and Yield per vine can be considered as suitable selection criteria for the improvement of high yielding bottle gourd varieties. 


\section{REFERENCES}

Burton, G.W. (1952) Quantitatve inheritance in grasses. Proceedings of 6th International Grassland congres. 11:277-283.

Burton, G.W, and Devane, C.H.(1953) Estimating heritability in tall fescue (Festuca arundinacea) from replicated clonal material. Agronomy Journal 45:478-481.

Jat, R. K., Ameta, K.D. and Choudhary, R.C. (2014) Genetic variability, heritability and genetic advance for yield and yield attributing traits in valan kakri (Cucumis sativus var. utilismus L.). The Ecoscan 6: 317- 322.

Johnson, H. W., Robinson, H. F., and Comstock, R. I. (1955) Estimates of genetic and environmental variability in soybean. Agronomy Journal 47: 314-318.

Hanchinamani, C.N., Patil, M.G., Dharmatti, P.R. and Mokashi, A.N. (2011) Studies on heritability and genetic advance in cucumber (Cucumis sativus L.). Crop Research 41(1, 2 \&3): 160-163.

Kumar, A.; Kumar, S. and Pal, A.K. (2008) Genetic variability and characters association for fruit yield and yield traits in cucumber. Indian Journal Horticulture 65(4): 423-428.

Kumar, S.; Kumar, D; Kumar, R; Thakur, K.S. and Dogra, B.S. (2013) Estimation of genetic variability and divergence for fruit yield and quality traits in cucumber (Cucumis sativus L.) in North-Western Himalayas. University Journal Plant Science 1(2): 27-36.

Panse V.G, Sukhatme P.V.(1957) Statistical methods for agricultural workers. Indian Council of Agricultural Research, New Delhi. 157-165.

Sanwal, S.K.; Yadav, R.K.; Rai, N.; Yadav, D.S. and Singh, P.K. (2007) Genetic diversity and interrelation analysis in sweet gourd (Momordica cochinchinensis) genotypes of Northeast India. Vegetable Science 34(1): 64- 66.

Samadia, D.K. (2011) Genetic variability studies in ridge gourd under arid environment. Indian Journal Horticulture 68(2): 275277.

Sivaraj, N. and Pandravada, S.R. (2005) Morphological diversity for fruit characters in bottle gourd germplasm from tribal pockets of Telangana region of Andhra Pradesh, India. Asian Agriculture History 9: 305-310

Singh, V., Naseeruddin, K. and Rana, D.K. (2014) Genetic variability of tomato genotypes for yield and other horticultural traits. Journal Hill Agriculture 5(2): 186-189. 